University of New Hampshire

University of New Hampshire Scholars' Repository

Faculty Publications

6-1-2008

\title{
NECROMASS PRODUCTION: STUDIES IN UNDISTURBED AND LOGGED AMAZON FORESTS
}

\author{
Michael W. Palace \\ University of New Hampshire, Durham, michael.palace@unh.edu \\ Michael M. Keller \\ University of New Hampshire, Durham, michael@kaos.sr.unh.edu \\ Hudson Silva \\ Universidade Federal do Pará
}

Follow this and additional works at: https://scholars.unh.edu/faculty_pubs

\section{Comments}

This is an article published by Ecological Society of America (ESA) in Ecological Applications in 2008, available

online: https://dx.doi.org/10.1890/06-2022.1

\section{Recommended Citation}

Palace, M., M. Keller, H. Silva, (2008b). Necromass production: studies in undisturbed and logged Amazon forests. Ecological Applications: 18, 873-884.

This Article is brought to you for free and open access by University of New Hampshire Scholars' Repository. It has been accepted for inclusion in Faculty Publications by an authorized administrator of University of New Hampshire Scholars' Repository. For more information, please contact Scholarly.Communication@unh.edu. 


\title{
NECROMASS PRODUCTION: STUDIES IN UNDISTURBED AND LOGGED AMAZON FORESTS
}

\author{
Michael Palace, ${ }^{1,5}$ Michael Keller, ${ }^{1,2,3}$ and Hudson Silva ${ }^{4}$ \\ ${ }^{1}$ Complex Systems Research Center, Morse Hall, University of New Hampshire, Durham, New Hampshire 03824 USA \\ ${ }^{2}$ International Institute of Tropical Forestry, USDA Forest Service, Rio Piedras, Puerto Rico 00928-5000 USA \\ ${ }^{3}$ Centro de Energia Nuclear na Agricultura, Universidade de Sao Paulo, Piracicaba, SP 13416-000, Brazil \\ ${ }^{4}$ Universidade Federal do Pará, Santarém, Pará, Brazil
}

\begin{abstract}
Necromass stocks account for up to $20 \%$ of carbon stored in tropical forests and have been estimated to be 14-19\% of the annual aboveground carbon flux. Both stocks and fluxes of necromass are infrequently measured. In this study, we directly measured the production of fallen coarse necromass $(\geq 2 \mathrm{~cm}$ diameter) during 4.5 years using repeated surveys in undisturbed forest areas and in forests subjected to reduced-impact logging at the Tapajos National Forest, Belterra, Brazil $\left(3.08^{\circ} \mathrm{S}, 54.94^{\circ} \mathrm{W}\right)$. We also measured fallen coarse necromass and standing dead stocks at two times during our study. The mean (SE) annual flux into the fallen coarse necromass pool in undisturbed forest of $6.7(0.8) \mathrm{Mg} \cdot \mathrm{ha}^{-1} \cdot \mathrm{yr}^{-1}$ was not significantly different from the flux under a reduced-impact logging of $8.5(1.3) \mathrm{Mg} \cdot \mathrm{ha}^{-1} \cdot \mathrm{yr}^{-1}$. With the assumption of steady state, the instantaneous decomposition constants for fallen necromass in undisturbed forests were $0.12 \mathrm{yr}^{-1}$ for large, $0.33 \mathrm{yr}^{-1}$ for medium, and $0.47 \mathrm{yr}^{-1}$ for small size classes. The mass weighted decomposition constant was $0.15 \mathrm{yr}^{-1}$ for all fallen coarse necromass. Standing dead wood had a residence time of 4.2 years, and $\sim 0.9$ $\mathrm{Mg} \cdot \mathrm{ha}^{-1} \cdot \mathrm{yr}^{-1}$ of this pool was respired annually to the atmosphere through decomposition. Coarse necromass decomposition at our study site accounted for $12 \%$ of total carbon remineralization, and total aboveground coarse necromass was $14 \%$ of the aboveground biomass. Use of mortality rates to calculate production of coarse necromass leads to an underestimation of coarse necromass production by 45\%, suggesting that nonlethal disturbance such as branch fall contributes significantly to this flux. Coarse necromass production is an important component of the tropical forest carbon cycle that has been neglected in most previous studies or erroneously estimated.
\end{abstract}

Key words: Amazon; coarse woody debris; dead wood; decay; decomposition; mortality; necromass; reduced-impact logging; standing dead; tropical forest.

\section{INTRODUCTION}

Necromass, including fallen and standing dead wood, is a major component of the carbon cycle in tropical forests. Aboveground coarse necromass $(\geq 2 \mathrm{~cm}$ diameter) accounts for up to $20 \%$ of carbon stored above ground and for $14-19 \%$ of the annual aboveground carbon flux in tropical forests (Kira 1978, Grove 2001, Clark et al. 2002, Chambers et al. 2004, Rice et al. 2004, Palace et al. 2007). The stock of necromass in a forest results from the balance of two processes, production and decay. Knowledge of these two processes is important for understanding carbon dynamics in tropical forests, yet for coarse necromass, the processes are infrequently studied (Kira 1978, Harmon et al. 1995, Keller et al. 2004b).

Necromass stocks above ground include fine litter and coarse necromass where coarse necromass has generally been defined as necromass with a diameter $>2 \mathrm{~cm}$

Manuscript received 8 December 2006; revised 4 September 2007; accepted 26 October 2007; final version received 28 November 2007. Corresponding Editor: A. R. Townsend.

${ }^{5}$ E-mail: michael.palace@unh.edu
(Harmon et al. 1986). Coarse necromass is often divided into two categories: (1) fallen or downed necromass, and (2) standing dead wood (snags) (Harmon et al. 1986). In the Brazilian Amazon, estimates of fallen necromass stocks in undisturbed forests in terra firma have included $42.8 \mathrm{Mg} \mathrm{C} / \mathrm{ha}$ (Summers 1998) and $48.0 \mathrm{Mg}$ $\mathrm{C} / \mathrm{ha}$ (Rice et al. 2004) on the higher end and $27.6 \mathrm{Mg}$ $\mathrm{C} / \mathrm{ha}$ (Keller et al. 2004b), $15 \mathrm{Mg} \mathrm{C} / \mathrm{ha}$ (Brown et al. 1995), 16.5 Mg C/ha (Gerwing 2002), and 2.9 Mg C/ha (Scott et al. 1992) on the lower end. Brown (1997) estimated necromass to range from $5 \%$ to $40 \%$ of the total carbon in tropical forests, a wide range with much uncertainty. Standing dead necromass is less studied than fallen necromass, yet has been found to account for $12-17 \%$ of the total necromass in a forest (Palace et al. 2007). Land use change directly alters carbon cycling in terrestrial ecosystems, both in terms of storage and exchange with the atmosphere. Land use has been shown to change both fallen and standing necromass stocks, through such processes as fire, agricultural practices, and selective logging (Uhl et al. 1988, Keller et al. 2004b, Eaton and Lawrence 2006, Palace et al. 2007). 
Decomposition of wood is generally a slow process that involves biological, chemical, and physical processes (Kaarik 1974). Necromass decomposition rates and constants have been measured directly and estimated using simple models in recent studies in the Brazilian Amazon. Chambers et al. (2000, 2001b) used two different measurement approaches (closed chambers using an infrared gas analyzer and directly measured density changes to approximate mass loss) and estimated decomposition constants of necromass to be 0.13 and $0.17 \mathrm{yr}^{-1}$ in forest sites near Manaus. Rice et al. (2004) combined measured tree mortality rates of $1.7 \%$ per year and an empirical decomposition model (Chambers et al. 2000) to estimate a decomposition constant of $0.12 \mathrm{yr}^{-1}$. Palace et al. (2007) estimated decomposition of necromass at Tapajos to be $0.14 \mathrm{yr}^{-1}$, using measurements of the biomass and necromass pools and literature estimates of the mortality rate for the Tapajos site.

Death of whole trees or portions of trees produces necromass, but rates of such production have been studied rarely in tropical forests. In a few recent studies, both direct measurements of fallen debris and mortality data have been used to estimate coarse necromass production. Clark et al. (2002) measured 4.8 $\mathrm{Mg} \cdot \mathrm{ha}^{-1} \cdot \mathrm{yr}^{-1}$ production of fallen coarse necromass using three repeated surveys in wet forest in Costa Rica. Eaton and Lawrence (2006), using repeated surveys, found necromass production to be $0.9 \mathrm{Mg} \cdot \mathrm{ha}^{-1} \cdot \mathrm{yr}^{-1}$ in an undisturbed dry tropical forest in Mexico. Rice et al. (2004) estimated a coarse necromass production of 4.8 $\mathrm{Mg} \cdot \mathrm{ha}^{-1} \cdot \mathrm{yr}^{-1}$ using mortality rates from the Tapajos National Forest near Santarem, Brazil. Chambers et al. (2000) estimated the production of dead wood in a forest near Manaus was $4.2 \mathrm{Mg} \cdot \mathrm{ha}^{-1} \cdot \mathrm{yr}^{-1}$, based on observed mortality rates as well. Using a steady state model, biomass stock measurements, published mortality data, and measurements of necromass stocks, Palace et al. (2007) estimated coarse necromass production at the Tapajos National Forest to be $8.5 \mathrm{Mg} \cdot \mathrm{ha}^{-1} \cdot \mathrm{yr}^{-1}$.

In the Amazon region, drastic changes in land use are occurring (Roberts et al. 2003, Keller et al. 2004a). Land use change directly alters carbon cycling in terrestrial ecosystems, both in terms of storage and exchange with the atmosphere. One land use practice, selective logging, affects 15000 to $20000 \mathrm{~km}^{2} / \mathrm{yr}$ in the Brazilian Amazon (Asner et al. 2005, 2006), changing the storage and cycling of carbon in the coarse necromass pools (Gerwing 2002, Keller et al. 2004b, Feldpausch et al. 2005, Palace et al. 2007). Selective logging actively fells a few trees per hectare, but much of the impact associated with logging results from clearing of roads, log landings, and skid trails (Pereira et al. 2002). These activities generate coarse necromass directly, as well as potentially altering tree mortality, and therefore coarse necromass production for at least two years after logging (Schulze and Zweede 2006).

Reduced-impact logging (RIL) is an approach to selective logging that minimizes the damage to the forest as compared to conventional selective logging (CL). Methods employed include tree surveys, vine cutting, road and skid planning, wheeled skidders, and planned directional felling (Pereira et al. 2002). Palace et al. (2007) found that coarse necromass stocks were 1.5 times greater in RIL sites one year following logging compared to undisturbed forests in Northwest Mato Grosso, Brazil. Keller et al. (2004b) found that CL generated 2.7 times as much fallen coarse necromass compared to RIL sites in Eastern Para, Brazil.

As part of the Large Scale Biosphere-Atmosphere Experiment in Amazonia (LBA; Keller et al. 2004a), studies are underway to refine estimates of forest ecosystem carbon storage and fluxes at regional and local scales (Keller et al. 2004b, Miller et al. 2004, Rice et al. 2004, Ometto et al. 2005). In LBA plot-based studies of forest stands, as in other forest studies, living biomass is separated from both standing and fallen necromass (e.g., Baker et al. 2004). Net carbon flux in forest stands has been expressed as the difference between the carbon increment from the growth of woody biomass minus the carbon lost through tree mortality. By convention, both of these quantities are most frequently measured for trees $>10 \mathrm{~cm}$ diameter at breast height $(\mathrm{dbh}=1.3 \mathrm{~m})$. Carbon fluxes measured this way in stand studies and quantified on an annual basis do not account for the variable production and the relatively slow decomposition of dead wood (Chave et al. 2003, Rice et al. 2004). Comparisons that have indicated reasonable agreement between plot studies and the net ecosystem exchange measurements made using the eddy covariance technique have accounted for coarse necromass stocks and adjusted fluxes to account for coarse necromass decomposition (e.g., Saleska et al. 2003).

Clark et al. (2001b) pointed out that forest productivity measurements do not necessarily account for branch fall and other nonlethal disturbances such as crown damage or heart rot. It is difficult to account for all nonlethal disturbances directly. For example, branches may die and remain attached to trees where they decay. Heart rot is concealed within a tree. However, we note that in a recent study for a forest near Manaus, Brazil, hollows accounted for only $0.6 \%$ of stem volume (Nogueira et al. 2005).

In the present study, we were interested in quantifying the production of necromass in both intact forests and forests affected by RIL logging. Necromass production has rarely been measured in tropical forests, and we hypothesized that necromass production estimates based on mortality rates would underestimate measured necromass production. We quantified the production of fallen coarse necromass in a tropical forest over 4.5 years using repeated surveys and attempted to separate the components of this flux owing to branches and stems. We also looked separately at the stocks and loss of standing dead material. We studied the dynamics of coarse necromass in both undisturbed forest (UF) and forests logged using reduced-impact logging (RIL) 
techniques. We compared necromass production estimates calculated from mortality rates to our field survey data.

\section{Methods \\ Sites}

We examined coarse necromass production and stocks at the Tapajos National Forest, located south of Santarem, Para, Brazil $\left(3.08^{\circ} \mathrm{S}, 54.94^{\circ} \mathrm{W}\right)$. The mean annual temperature is $\sim 25^{\circ} \mathrm{C}$ and the mean annual precipitation is $\sim 2000 \mathrm{~mm} / \mathrm{yr}^{-1}$, with a six-month-long dry season (Silver et al. 2000). The forest aboveground live biomass is $\sim 282 \mathrm{Mg} /$ ha (Keller et al. 2001). Our study area included two forest treatment types; one area that was selectively logged using RIL methods and an undisturbed forest (UF). RIL treatments were logged in 2000. Within each forest type, we sampled two $\sim 100$-ha management blocks. These same areas were examined in Keller et al. (2004b) for coarse necromass density and our initial fallen coarse necromass volume and mass measured in 2001. The initial standing dead pool, measured in January 2002, was presented in Palace et al. (2007). Comprehensive descriptions of the study sites and the logging techniques are found in Keller et al. (2001, 2004b) and Palace et al. (2007).

\section{Production of fallen coarse necromass}

Fallen coarse necromass production in two treatments (RIL and UF) was measured using repeated lineintercept transects conducted approximately every six months during 4.5 years from November 2001 through February 2006. Because of differences among sampling intervals (105 to 257 days), reported values have been adjusted to annual rates. We repeatedly sampled the same line-intercept transects (total length, $11.1 \mathrm{~km}$ ) with two blocks per treatment, each containing three or four transects. The two RIL blocks were sampled using 2.3 and $2.8 \mathrm{~km}$ of line-intercept transects, and the two UF blocks were each sampled using $3 \mathrm{~km}$ of line-intercept transects. We established the transects six months before our initial measurements conducted in November 2001 by painting and marking all initial necromass crossing the transect lines using the methods described in the next paragraph.

Coarse necromass volume measurements were made using line-intersect transects (Brown 1974, de Vries 1986, Ringvall and Stahl 1999). Necromass is measured along the plane defined by the line transect and perpendicular plumb line. Volume per unit area $(V$; $\mathrm{m}^{3} / \mathrm{ha}$ ) of fallen coarse woody debris (CWD) for an individual transect is calculated using the following equation:

$$
\frac{V=\pi^{2} \sum\left(d_{\mathrm{n}}\right)^{2}}{(8 \times L)}
$$

where $d_{\mathrm{n}}$ (in centimeters) is the diameter of a piece of necromass at the line intercept and $L$ (in meters) is the length of the transect used in sampling (de Vries 1986).

We separated coarse necromass into three diameter groups, $>10 \mathrm{~cm}$ diameter (large), 5-10 cm (medium), and $2-5 \mathrm{~cm}$ (small). Fallen coarse necromass with a diameter $<2 \mathrm{~cm}$ was disregarded, as it is generally included in litterfall studies (Keller et al. 2004b). We recorded diameters for all large necromass pieces intersecting the vertical plane defined by the transect line (Brown 1974). We divided each transect into 50-m segments. Within each $50-\mathrm{m}$ segment of the transect line, we selected at random a $10-\mathrm{m}$ section and counted the number of small and medium necromass pieces intersecting this subsample. All large coarse necromass was painted with durable spray enamel during each survey so that the existing necromass could be separated from newly fallen necromass on subsequent surveys; small and medium necromass material was removed from the sample line because painting was impractical. In order to precisely identify the $10-\mathrm{m}$ subsampling locations, during every repeat survey, we attached nylon mason line to two large nails pushed into the soil and marked the area with flagging tape. Occasionally between surveys, nylon lines disappeared or were cut by leaf cutter ants, peccaries, or human hunters (13.9\%). If a subsample nylon line was cut or if it could not be found, a new subsample was randomly selected within the $50-\mathrm{m}$ section and no data on small and medium classes were collected for that subsample for that time interval with an adjustment made to account for the lower number of subsamples collected.

Each large coarse necromass piece was classified into one of five decay classes (Harmon et al. 1986), ranging from newly fallen necromass with twigs and dead leaves attached (Class 1) to highly decayed material that could be broken apart by hand (Class 5) (Harmon et al. 1995, Keller et al. 2004b). We assigned a mean bulk density value to each class using the same decay class densities measured at Tapajos by Keller et al. (2004b) and used in our initial stock estimates. For the two smaller size classes we used a single mean bulk density measurement for each size class determined at Tapajos (Keller et al. 2004b). During the final five surveys (January 2003 to November 2004), we classified the sources of each piece of coarse necromass measured as either trunk, branch, or unidentifiable.

Coarse necromass was determined from the product of the volume of material and the respective density of each piece's decay class or size class for small and medium diameter pieces (Harmon et al. 1995, Keller et al. 2004b). When we calculated necromass volume, median diameters for small and medium size classes were used $(3.5$ and $7.5 \mathrm{~cm}$, respectively; Keller et al. 2004b). We used means weighted by transect length when calculating volume and mass measured from lineintercept transects (de Vries 1986).

We note that necromass decomposes between collection periods, and therefore we measured a net necromass 
production (production minus decomposition). We sampled at six-month intervals as a compromise between maintaining a reasonable volume of collection (and economy of the study) and the loss of material through decomposition. The average residence time of necromass was $\sim 14$ times the collection interval. Therefore, the importance of decomposition was minimal on average and, for simplicity, we avoid using the term "net production."

\section{Coarse necromass pool measurement}

In 2004, three years after our initial coarse necromass pool measurements presented in Keller et al. (2004b), we conducted a new series of line-intersect transects to measure the fallen coarse necromass volume. These were conducted in the same treatments and blocks as our initial measurements (Keller et al. 2004b). Line placement in our initial study of necromass stocks (Keller et al. 2004b) was selected at random locations along an edge of a rectangular study block $(1000 \times 1000 \mathrm{~m})$. Lines were parallel and separated by at least $100 \mathrm{~m}$ (Keller et al. 2004b). We oriented these lines in logged blocks to cross logging roads at approximately right angles New line-intersect transects, measured in this study, were randomly selected, but systematically parallel to existing lines, with spacing between new lines and existing lines of at least $50 \mathrm{~m}$. We did not resample the same line transects used in the initial coarse necromass pool estimate because foot traffic and removal of coarse necromass from the repeated survey lines would have introduced biases for a resurvey of fallen coarse necromass stocks. For the new fallen coarse necromass pool estimates we sampled a total $12 \mathrm{~km}$ of line-intercept transects (two treatments $\times$ two blocks $\times$ three one-km transects per block). We used the same method to estimate coarse necromass volume and mass as described in our repeated sampling surveys. We classified the source of each piece of necromass in our new lineintersect transects as trunk, branch, or unidentifiable. Determination of coarse necromass source was not attempted in our initial pool measurements (Keller et al. 2004b).

We also resurveyed the standing dead (snag) pool in 2004, to compare with initial pool measurements made in 2002 (Palace et al. 2007). Standing dead volume measurement used strip plots that were $10 \mathrm{~m}$ wide along the length of the line-intercept transects $(\sim 1000 \mathrm{~m})$. The total area resampled for the standing dead necromass pool was 11.1 ha, 5.1 ha were sampled in the RIL treatment (2.3 and 2.8 ha in two blocks), and 6 ha were sampled in the undisturbed forest ( 3 ha in each of two blocks). We used the same five-group decay class classification used in fallen coarse necromass surveys. A laser ranger finder with a built-in clinometer was used to measure snag height (Impulse-200LR, Laser Technology, Englewood, Colorado, USA). The dbh was recorded for all snags taller than $1.3 \mathrm{~m}$. For snags shorter than $1.3 \mathrm{~m}$, we measured the highest point of the snag and the diameter at the highest point. Volume estimates for snags used the disc method of integration, a taper function (Chambers et al. 2001a), and height and diameter measurements (Palace et al. 2007). Mass was calculated by multiplying the volume of a snag by its respective decay class density (Keller et al. 2004b, Palace et al. 2007).

When we conducted our initial sample of standing dead in 2002, we placed a $20 \mathrm{~cm}$ long steel nail attached with numbered flagging tape at the base of each snag. In 2004, we used a metal detector to locate nails and differentiate new snags from those previously measured. The repeated sampling allowed us to determine changes in the pool of standing necromass and residence time in this pool. In order to avoid double counting, we did not use this data to calculate the decomposition constant and residence time for the overall fallen necromass pool, because some standing dead falls between survey periods.

\section{Statistical analysis}

We conducted a repeated-measures multivariate analysis of variance (MANOVA) for comparison of treatments (UF and RIL) across repeated sampling times for each of the pool components that we measured (small, medium, and large size classes, total fallen coarse necromass, and standing dead). We also examined the treatment $\times$ time interactions. Statistical significance was considered for results using $\alpha \leq 0.05$. The total coarse necromass (fallen coarse necromass plus standing dead) was not examined with statistical tests because of different sample areas and methods in data collection between fallen and standing necromass. Because the forest area of Tapajos was continuous prior to logging operations, the undisturbed forest blocks may be considered pseudoreplicates. Therefore, we recognize that the interpretation of the statistical tests should formally be limited to the experimental domain.

We conducted a series of chi-square tests to examine the proportions of fallen coarse necromass that came from branches, trunks, or undefined sources. We examined production and pool necromass estimates using proportions of total mass for each source to normalize for variable mass (RIL and UF) and different methodology between pool and production measurements. Our analyses examined: (1) proportions between treatments within a source (pool or production), and (2) proportions within treatment and between sources. Results were considered statistically significant for $\alpha \leq$ 0.05 .

\section{Simple model to examine dynamics}

A simple compartmental model of necromass dynamics was developed with three compartments, one for each of the three size classes of fallen necromass. We did not consider transfers among size classes. We also used a single-box model that combined all fallen coarse necromass size classes. The basic model is as follows: 
TABLE 1. Mean and standard errors ( $n=2$ blocks per treatment) for production of necromass over a four- and one-half-year period at Tapajos National Forest, Para, Brazil.

\begin{tabular}{|c|c|c|c|c|c|c|}
\hline \multirow[b]{3}{*}{ Size class } & \multicolumn{3}{|c|}{ RIL } & \multicolumn{3}{|c|}{ UF } \\
\hline & \multicolumn{2}{|c|}{ Mass $\left(\mathrm{Mg} \cdot \mathrm{ha}^{-1} \cdot \mathrm{yr}^{-1}\right)$} & \multirow{2}{*}{$\begin{array}{c}\text { Percentage } \\
\text { of total }\end{array}$} & \multicolumn{2}{|c|}{$\operatorname{Mass}\left(\mathrm{Mg} \cdot \mathrm{ha}^{-1} \cdot \mathrm{yr}^{-1}\right)$} & \multirow{2}{*}{$\begin{array}{c}\text { Percentage } \\
\text { of total }\end{array}$} \\
\hline & Mean & SE & & Mean & $\mathrm{SE}$ & \\
\hline Large & 6.4 & 1.5 & 75 & 4.7 & 0.7 & 70 \\
\hline Small & 0.9 & 0.0 & 10 & 0.8 & 0.2 & 12 \\
\hline Medium & 1.3 & 0.3 & 15 & 1.2 & 0.1 & 18 \\
\hline Total fallen & 8.5 & 1.3 & 100 & 6.7 & 0.8 & 100 \\
\hline
\end{tabular}

Note: Key to abbreviations: RIL, reduced-impact logging; UF, undisturbed forest.

$$
d M_{i} / d t=-k_{i} M_{i}+F_{i}
$$

where $M_{i}$ is the necromass pool $(\mathrm{Mg})$ for a given size class $(i)$ or the aggregate necromass pool, $F_{i}$ is the rate of necromass production $\left(\mathrm{Mg} \mathrm{yr}^{-1}\right)$, and $k_{i}$ is the decomposition constant $\left(\mathrm{yr}^{-1}\right)$. By definition, at steady state $d M / d t$ is zero, meaning that the amount of necromass produced is the same as the amount that decays. The residence time $\left(\tau_{i}=1 / k_{i}\right)$ for necromass is $M$ divided by $F$.

\section{RESUlts}

\section{Necromass production}

We measured 668 large, 252 medium, and 1168 small pieces of necromass in our repeated line-intersect surveys. The initial production estimate in November 2001 only included one transect from RIL and one transect from the UF treatment. Because of this, the standard error could not be estimated and the mean might have been inflated due to under-sampling. We excluded this initial unreplicated sample period from our statistical analysis.

The fallen coarse necromass generated during the study for the RIL treatment was $8.5 \pm 1.3 \mathrm{Mg} \cdot \mathrm{ha}^{-1} \cdot \mathrm{yr}^{-1}$ $\left(\right.$ mean $\pm \mathrm{SE}$ ) and was $6.7 \pm 0.8 \mathrm{Mg} \cdot \mathrm{ha}^{-1} \cdot \mathrm{yr}^{-1}$ for the UF treatment (Table 1). The sum of the small and medium size classes made up $30 \%$ of the total fallen coarse necromass produced in UF treatments and $25 \%$ in RIL treatments (Table 1). We found no significant difference between treatments for the production of fallen coarse necromass and no significant effect of time.

The time series showed a larger amount of fallen coarse necromass produced at the beginning of the study followed by a nearly constant and nearly identical rate of production in both RIL and UF treatments (Fig. 1). The maximum annualized total fallen coarse necromass produced for a single sampling period for the RIL treatment was $22.3 \pm 16.2 \mathrm{Mg} \cdot \mathrm{ha}^{-1} \cdot \mathrm{yr}^{-1}$ and for the UF treatment was $8.4 \pm 0.7 \mathrm{Mg} \cdot \mathrm{ha}^{-1} \cdot \mathrm{yr}^{-1}$. RIL and UF did not always have correspondingly high and low production measurements. In addition, small and medium necromass production estimates did not follow the same pattern as large necromass production estimates (Fig. 1). The minimum annualized coarse necromass production was $4.1 \pm 0.5$ and $3.5 \pm 0.4 \mathrm{Mg} \cdot \mathrm{ha}^{-1} \cdot \mathrm{yr}^{-1}$ for RIL and $\mathrm{UF}$, respectively.
The high value for the RIL forest type in the November 2004 sample period was due to one large newly fallen $155 \mathrm{~cm}$ diameter tree. Removal of this single extremely large diameter fallen necromass piece changed the RIL necromass production estimate of $22.3 \pm 16.2$ to $9.1 \pm 3.0 \mathrm{Mg} \cdot \mathrm{ha}^{-1} \cdot \mathrm{yr}^{-1}$ for that sample period. This calculation was done merely for illustration. Statistical analyses used the entire data set.

\section{Necromass pool estimates}

We measured the volume of 578 snags in November 2004 compared to 640 snags measured in the same 11.1 ha in 2002 (Palace et al. 2007). Based on the MANOVA analysis, the logging treatment had no significant effect on the standing dead stocks when compared to the undisturbed forest, and there was no significant change in stocks over time, though our power to detect differences was low. Standing dead mass in the RIL treatment decreased between 2002 and 2004 from our initial measurement of $12.9 \pm 4.6 \mathrm{Mg} / \mathrm{ha}$ and our measurement two years later in this study at $10.0 \pm 1.9$ $\mathrm{Mg} /$ ha (Table 2). The standing dead measured in undisturbed forest increased during this time, with 7.7 $\pm 2.0 \mathrm{Mg} / \mathrm{ha}$ in 2002 and $8.1 \pm 3.2 \mathrm{Mg} / \mathrm{ha}$ in 2004 (Table 2).

Total fallen coarse necromass was $74.4 \pm 14.2 \mathrm{Mg} / \mathrm{ha}$ for RIL treatments and $40.8 \pm 4.7 \mathrm{Mg} / \mathrm{ha}$ for $\mathrm{UF}$ treatments in 2004 (Table 2). Mass of small and large classes of fallen coarse necromass and total fallen coarse necromass showed no significant differences for treatment or time. The medium size class was found to be significantly different for time, treatment, and time $\times$ treatment interaction (Table 2). In our 2004 resurvey, small and medium size classes for fallen coarse necromass made up $7 \%$ of the total fallen coarse necromass in RIL treatments and $11 \%$ in UF treatments. RIL treatments had $58 \%$ more total coarse necromass (total fallen and standing dead) than UF treatments (Table 2). No statistical comparison was conducted on total coarse necromass (including standing dead) because of differences in methodology and sampling area between standing dead and fallen coarse necromass pools. 

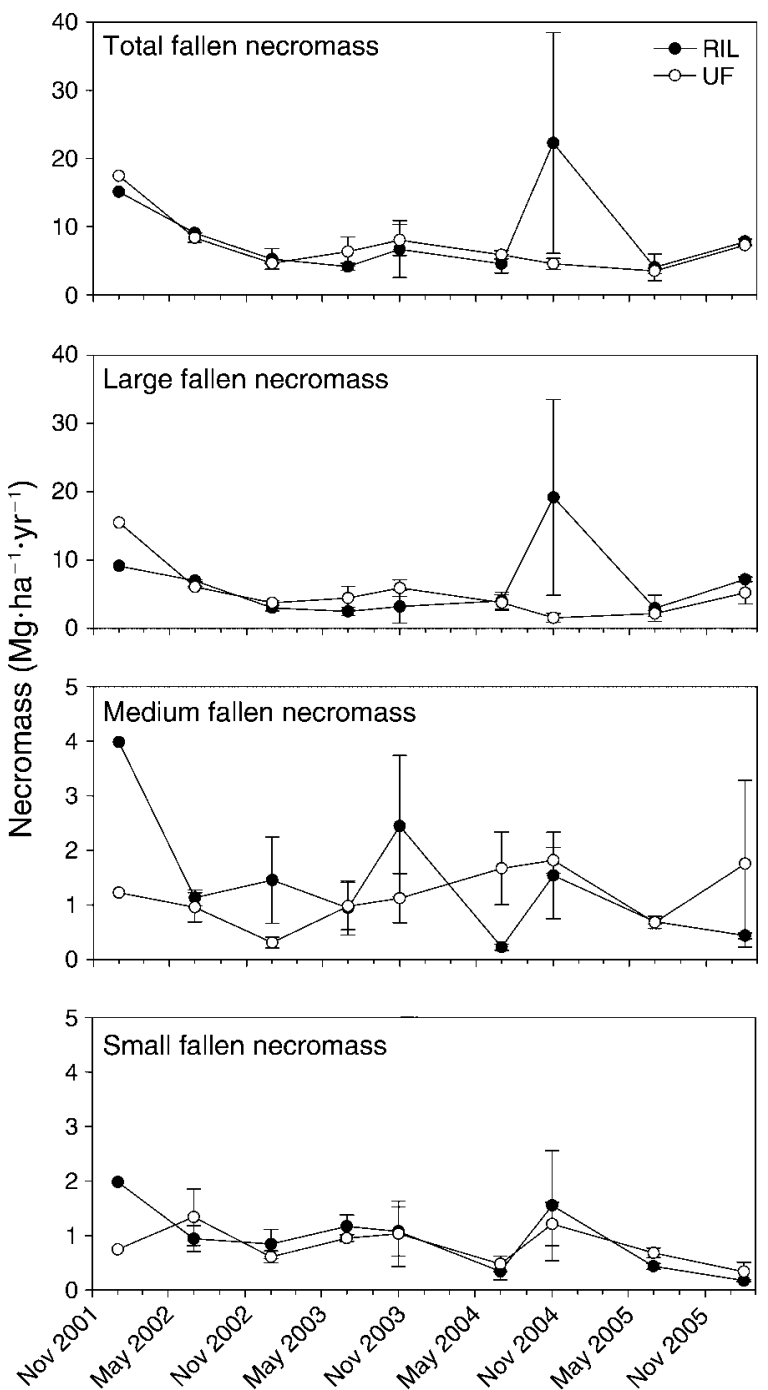

FIG. 1. Flux of newly fallen coarse necromass shown for reduced-impact logging (RIL; solid circles) and undisturbed forest (UF; open circles) treatments for nine sampling periods. The fluxes have been annualized for comparison among variable sampling periods. Error bars are standard errors of the mean ( $n=2$ blocks). Error bars are not included for the first time period because only one transect was measured in each treatment. Medium and small fallen necromass classes are presented on a different scale compared to large and total fallen coarse necromass.

\section{Proportion of necromass source}

Necromass derived from tree trunks dominated the large size class in both necromass production and in pools (Table 3 ). The other size classes were more evenly distributed among sources. We found significant differences between treatments for the proportions of trunk, branch, and unidentified material within both production and pool necromass $\left(\chi^{2}, P<0.0001\right)$. Within a treatment proportions between groups (production and pool estimates) were also found to be significantly different $\left(\chi^{2}, P<0.0001\right)$.

\section{Simple model outputs}

We used measured necromass production (Table 1) together with the mean of stock estimates from 2001 and 2004 (Table 2) and the assumption of steady state to calculate decomposition constants for necromass using our simple compartment model (Eq. 2; Table 4). We calculated necromass decomposition constants $(k)$ to be $0.12 \mathrm{yr}^{-1}$ for the large size class, $0.33 \mathrm{yr}^{-1}$ for the medium size class, and $0.47 \mathrm{yr}^{-1}$ for the small size class; the overall decomposition constant for all fallen coarse necromass was $0.15 \mathrm{yr}^{-1}$. Calculated residence times ( $\tau=$ $1 / k$ ) are 8.6, 3.0, and $2.1 \mathrm{yr}$ for the large, medium, and small size classes, respectively (Tables 4 and 5).

For standing dead, in undisturbed forests, we based our model on our initial measurement of standing dead stock (Palace et al. 2007) and the measurement of new standing dead two years later (Table 6). We found that 1.9 $\mathrm{Mg} \cdot \mathrm{ha}^{-1} \cdot \mathrm{yr}^{-1}$ of standing dead was produced. Considering this value, we calculated the rate of movement through the pool to be $0.24 \mathrm{yr}^{-1}$ with a corresponding residence time of 4.2 years. Using the decomposition constant estimated for large fallen necromass we estimate respiration losses from the standing dead pool of $0.9 \mathrm{Mg} \cdot \mathrm{ha}^{-1} \cdot \mathrm{yr}^{-1}$. The two studies, Lang and Knight (1979) and Odum (1970), provide estimates of standing dead decomposition of 0.461 per year and 0.115 per year. The Odum (1970) estimate is very similar to the estimate used in our study, 0.12 per year. The use of 0.12 per year generates a more conservative estimate of bole respiration. Standing dead necromass dynamics in a RIL treatment was similar to undisturbed forest standing dead (Table 6).

\section{Discussion}

\section{Production and decomposition of necromass}

Fallen CWD production measured over a 4.5 -year period was greater under the RIL treatment $(8.5 \pm 1.3$ $\left.\mathrm{Mg} \cdot \mathrm{ha}^{-1} \cdot \mathrm{yr}^{-1}\right)$ compared to the undisturbed treatments $\left(6.7 \pm 0.8 \mathrm{Mg} \cdot \mathrm{ha}^{-1} \cdot \mathrm{yr}^{-1}\right)$, although the difference was not statistically significant. An examination of Fig. 1 clearly shows that total and large necromass amounts were all but identical for RIL and UF for all time periods with the exception of November 2004. The extraordinary production of necromass recorded in November 2004 could be traced directly to a single storm event in October of 2004 that closed the roads to our site for two days until debris could be cleared by crews working with chainsaws. We do not know if storm winds hit hardest only at the one RIL block that registered a high necromass production or if that block was differentially susceptible to wind. However, this was a unique event over our sampling period.

Although our study was more extensive spatially and temporally than any other study of coarse necromass production at a tropical forest site, the effect of a single large tree fall $(>150 \mathrm{~cm}$ diameter) registered in November 2004 had a substantial effect on the 
TABLE 2. Coarse necromass pools at Tapajos from two sample periods (2001 and 2004).

\begin{tabular}{|c|c|c|c|c|c|c|c|c|}
\hline \multirow[b]{2}{*}{ Treatment measurement } & \multicolumn{2}{|c|}{ RIL, $2001(\mathrm{Mg} / \mathrm{ha})$} & \multicolumn{2}{|c|}{ RIL, $2004(\mathrm{Mg} / \mathrm{ha})$} & \multicolumn{2}{|c|}{ UF, $2001(\mathrm{Mg} / \mathrm{ha})$} & \multicolumn{2}{|c|}{ UF (2001) $(\mathrm{Mg} / \mathrm{ha})$} \\
\hline & Mean & $\mathrm{SE}$ & Mean & SE & Mean & SE & Mean & SE \\
\hline Standing dead & 12.9 & 4.6 & 10.0 & 1.9 & 7.7 & 2.0 & 8.1 & 3.2 \\
\hline Total fallen & 72.6 & 10.4 & 74.4 & 14.2 & 50.7 & 1.1 & 40.8 & 4.7 \\
\hline Fallen small & 5.3 & 1.4 & 1.2 & 0.1 & 1.9 & 0.4 & 1.4 & 0.0 \\
\hline Fallen medium & 10.0 & 0.1 & 3.5 & 0.4 & 4.0 & 1.0 & 3.2 & 0.3 \\
\hline Fallen large & 57.4 & 9.0 & 69.7 & 14.7 & 44.7 & 0.4 & 36.3 & 1.8 \\
\hline Total all necromass & 85.5 & 14.9 & 84.4 & 16.1 & 58.4 & 3.1 & 49.0 & 1.1 \\
\hline
\end{tabular}

Notes: Standing dead was measured in 2002 and 2004. Only the fallen coarse medium size class was found to be significantly different for sampling period $(\mathrm{p})$, treatment $(\mathrm{t})$, and sampling period $\times$ treatment interaction $(\mathrm{p} \times \mathrm{t})$. Total all necromass was not examined for differences due to differing sampling areas measured and methodology in data collection for standing dead and fallen necromass. RIL, reduced-impact logging; UF, undisturbed forest.

necromass production measurement for the RIL treatment at that time and in the overall study average. This single event more than doubled the annualized necromass production for the RIL sites during the sampling period. Trees of this size or greater occur with a frequency of only about $0.079 \mathrm{ha}^{-1}$ at Tapajos based on a 400-ha survey (Keller et al. 2001). Assuming that we adequately sampled our 100-ha blocks, we would have only 7.9 trees of this size class per 100-ha block. If these trees have a $1.7 \%$ annual mortality rate (Rice et al. 2004), then our chance of seeing a fall of this size is (1 $0.983^{7.9}$ ) or $12.7 \%$ per year per 100 -ha block. Considering that our study was conducted over a 4.5-year period, our estimate of the probability of encountering a tree fall $>150 \mathrm{~cm} \mathrm{dbh}$ is $\left(1-0.873^{4.5}\right)$ or $45.7 \%$ per block. In order to have a $95 \%$ chance of measuring the death of one $150 \mathrm{~cm}$ diameter tree in a single year, we would need to sample an area that contained $\sim 175$ trees of this size equivalent to $\sim 2215$ ha, 10 times our sampling area for each treatment.

Our coarse necromass production estimate may represent a slight underestimate. About $0.8 \%$ of the biomass at Tapajos is found in trees $>150 \mathrm{~cm} \mathrm{dbh}$. If trees in this size class die on average with the same frequency of other trees (Swaine et al. 1987), then their contribution (by complete mortality) to coarse necromass production would be $\sim 2.4 \mathrm{Mg} /$ ha $\times 0.017 \mathrm{yr}^{-1}$, equal to $\sim 0.5 \%$ of the annual coarse necromass production that we measured, a small contribution to the overall coarse necromass production value.
There was a tendency for a greater amount of necromass created at the initial stages of our study for both RIL and UF treatments. Possibly a disturbance, not specific to the logged site, may have occurred on a landscape level. It has been suggested that large-scale mortality occurred at Tapajos in the late 1990s resulting from drought during the 1997-1998 El Niño (Saleska et al. 2003, Rice et al. 2004). Drought disturbances in tropical forests are known to increase mortality rates (Williamson et al. 2000). The elevated production of fallen coarse necromass early in our study may represent a delayed response to a landscape level disturbance. This long delay is plausible in light of the approximately fouryear residence time of standing dead. Alternatively, it is possible that the initial estimate of necromass production may be elevated simply because of under-sampling.

Studies that directly measured coarse necromass production in tropical forests are limited. These include $0.9 \mathrm{Mg} \cdot \mathrm{ha}^{-1} \cdot \mathrm{yr}^{-1}$ in a dry tropical forest in Mexico (Eaton and Lawrence 2006), $2 \mathrm{Mg} \cdot \mathrm{ha}^{-1} \cdot \mathrm{yr}^{-1}$ in Jamaica (Tanner 1980), $14.4 \mathrm{Mg} \cdot \mathrm{ha}^{-1} \cdot \mathrm{yr}^{-1}$ in Pasoh Forest in western Malaysia (Kira 1978), and $4.9 \mathrm{Mg} \cdot \mathrm{ha}^{-1} \cdot \mathrm{yr}^{-1}$ in Costa Rica (Clark et al. 2002). Eaton and Lawrence (2006) examined coarse necromass production in a dry tropical forest and found a higher amount of input during the dry season using four repeated measurements at six-month intervals. In our 4.5-year study, with nine repeated measurements conducted in a moist tropical forest at Tapajos, no seasonality was found in the

TABLE 3. Source proportions of fallen coarse necromass from production and pool measurements.

\begin{tabular}{lccccccr}
\hline \hline \multirow{2}{*}{$\begin{array}{c}\text { Treatment, } \\
\text { source }\end{array}$} & \multicolumn{3}{c}{ Production } & & \multicolumn{2}{c}{ Pool } \\
\cline { 2 - 3 } & Large & Medium & Small & & Large & Medium & Small \\
\hline RIL & & & & & & \\
$\quad$ Trunk & 0.79 & 0.22 & 0.20 & & 0.63 & 0.31 & 0.09 \\
Branch & 0.16 & 0.46 & 0.38 & & 0.32 & 0.47 & 0.66 \\
$\quad$ Unidentified & 0.05 & 0.32 & 0.41 & & 0.05 & 0.22 & 0.25 \\
UF & & & & & & \\
Trunk & 0.57 & 0.21 & 0.08 & & 0.74 & 0.22 & 0.04 \\
Branch & 0.35 & 0.57 & 0.53 & & 0.23 & 0.49 & 0.71 \\
$\quad$ Unidentified & 0.08 & 0.22 & 0.39 & 0.03 & 0.29 & 0.25 \\
\hline
\end{tabular}


TABLE 4. Results from a simple model to estimate pools and fluxes of coarse fallen necromass in an undisturbed forest assuming steady state.

\begin{tabular}{|c|c|c|c|c|}
\hline Site & Large & Medium & Small & Total \\
\hline Production of fallen coarse necromass $\left(\mathrm{Mg} \cdot \mathrm{ha}^{-1} \cdot \mathrm{yr}^{-1}\right)$ & 4.7 & 1.2 & 0.8 & 6.7 \\
\hline Fallen coarse necromass pool $\left(\mathrm{Mg} \cdot \mathrm{ha}^{-1} \cdot \mathrm{yr}^{-1}\right)$ & 40.5 & 3.6 & 1.7 & 45.8 \\
\hline Estimated decay rate if at steady state $\left(\mathrm{yr}^{-1}\right)$ & 0.12 & 0.33 & 0.47 & 0.15 \\
\hline Residence time (yr) & 8.6 & 3.0 & 2.1 & 6.8 \\
\hline
\end{tabular}

Note: Measured values are shown in boldface type.

production of fallen coarse necromass for both RIL and undisturbed treatments for any of the size classes.

In the Tapajos forest, Rice et al. (2004) calculated a coarse necromass production value of $4.8 \mathrm{Mg} \cdot \mathrm{ha}^{-1} \cdot \mathrm{yr}^{-1}$ using a mortality rate of $1.7 \% \mathrm{yr}^{-1}$ for trees $>10 \mathrm{~cm} \mathrm{dbh}$. Vieira et al. (2004) estimated a steady state live wood production in the Tapajos National forest of 3.0 $\mathrm{Mg} \cdot \mathrm{ha}^{-1} \cdot \mathrm{yr}^{-1}$ based on diameter increments implying that coarse necromass production was also 3.0 $\mathrm{Mg} \cdot \mathrm{ha}^{-1} \cdot \mathrm{yr}^{-1}$. These two estimates are $2-4 \mathrm{Mg} \cdot \mathrm{ha}^{-1} \cdot \mathrm{yr}^{-1}$ lower than our measurement of coarse necromass production for undisturbed forest at Tapajos. The difference between mortality-based estimates of wood or coarse necromass production and our measurements may reflect two problems with using mortality rates to estimate necromass production. First, mortality-based estimates of necromass production are most frequently applied to the biomass of trees only $>10 \mathrm{~cm} \mathrm{dbh}$, ignoring smaller trees, shrubs, and vines. These biomass components may be important components of overall forest productivity (Chave et al. 2003) and accounted for $21 \%$ of the total aboveground biomass at Tapajos (vines and trees $<15 \mathrm{~cm}$ dbh; Keller et al. 2001). Second, mortality-based estimates do not include nonlethal disturbance wherein only a portion of a tree dies. Clark et al. $(2001 a, b)$ noted the potential importance of branch fall to estimation of net primary productivity. Chave et al. (2003) found that branch falls and crown damage contributed $\sim 0.5 \mathrm{Mg} \cdot \mathrm{ha}^{-1} \cdot \mathrm{yr}^{-1}$ to aboveground biomass loss in a 50-ha forest plot at Barro Colorado, Panama. Chambers et al. (2001a) estimated that branch fall at an old-growth forest site near Manaus, Brazil was $0.9 \mathrm{Mg} \cdot \mathrm{ha}^{-1} \cdot \mathrm{yr}^{-1}$ based upon allometric arguments. Overall, underestimates of necromass production are likely due to a failure to account for mortality in all

TABLE 5. Necromass production and mortality calculations based on aboveground biomass of $282 \mathrm{Mg} / \mathrm{ha}$ (Keller et al. 2001) and a range of estimates based on field-measured values.

\begin{tabular}{ccc}
\hline \hline $\begin{array}{c}\text { Mortality } \\
\left(\mathrm{yr}^{-1}\right)\end{array}$ & $\begin{array}{c}\text { Necromass } \\
\text { production }\left(\mathrm{Mg} \mathrm{yr}^{-1}\right)\end{array}$ & $\begin{array}{c}\text { Decomposition } \\
\text { rate }\left(\mathrm{yr}^{-1}\right)\end{array}$ \\
\hline $\mathbf{0 . 0 1 5} \dagger$ & 4.2 & 0.08 \\
0.024 & $\mathbf{6 . 7}$ & 0.15 \\
$\mathbf{0 . 0 3 0} \dagger$ & 8.5 & 0.16 \\
\hline
\end{tabular}

Note: Measured values are shown in boldface type.

$\uparrow$ Schulze and Zweede (2006).

\$ Silva et al. (1995). biomass components and a failure to account for nonlethal disturbance.

Palace et al. (2007) estimated necromass production to be $8.5 \mathrm{Mg} \cdot \mathrm{ha}^{-1} \cdot \mathrm{yr}^{-1}$ using a mortality rate of $0.03 \mathrm{yr}^{-1}$ (Silva et al. 1995) and measured biomass from Keller et al. (2001) (Table 5). This mortality rate was selected from the high end of available mortality measurements for tropical moist forests in order to generate agreement with published estimates of coarse necromass decomposition. It was only by using a high rate of mortality, that Palace et al. (2007) could produce a reasonable fit to a simple model of necromass production and decomposition.

We calculated production of $4.2 \mathrm{Mg} \cdot \mathrm{ha}^{-1} \cdot \mathrm{yr}^{-1}$ for coarse necromass using a mortality rate of $1.5 \% \mathrm{yr}^{-1}$ from Schulze and Zweede (2006) and an aboveground biomass of $282 \mathrm{Mg} /$ ha from Keller et al. (2001) that included nontree components. This approach underestimates coarse necromass production by $2.5 \mathrm{Mg} \cdot \mathrm{ha}^{-1} \cdot \mathrm{yr}^{-1}$ (Table 5). Using this production amount and assuming steady state, the decomposition constant would be $0.08 \mathrm{yr}^{-1}$, only about one-half the decomposition constant we found using our production and stock measurements.

If we take measurements of coarse necromass production divided by an aboveground biomass of 282 $\mathrm{Mg} /$ ha from Keller et al. (2001) (Table 5), we calculate a mortality rate of $2.4 \% \mathrm{yr}^{-1}, 0.9 \%$ higher than the mortality rate of $1.5 \% \mathrm{yr}^{-1}$ observed by Schulze and Zweede (2006) (Table 5). We stress that using a mortality rate to estimate necromass production may lead to a substantial underestimation, in our case by $30-50 \%$. The additional coarse necromass production not accounted for by mortality is probably the result of snap-offs, branch falls, and other nonlethal disturbances.

\section{Necromass pools}

Our two pool measurements of necromass (Table 2) are consistent with literature values for tropical forests.

TABLE 6. Examination of standing dead pool and estimation of time in pool and respiration from the pool for undisturbed forested areas at Tapajos National Forest.

\begin{tabular}{lll}
\hline \hline \multicolumn{1}{c}{ Necromass component } & UF & RIL \\
\hline Standing dead pool $(\mathrm{Mg} / \mathrm{ha})$ & 7.9 & 8.3 \\
Standing dead new $\left(\mathrm{Mg} \cdot \mathrm{ha}^{-1} \cdot \mathrm{yr}^{-1}\right)$ & 1.9 & 1.8 \\
Rate of movement through pool $\left(\mathrm{yr}^{-1}\right)$ & 0.24 & 0.21 \\
Time in pool $(\mathrm{yr})$ & 4.2 & 4.7 \\
Estimated decomposition while in pool $\dagger$ & 0.9 & 1.0
\end{tabular}

$\dagger$ Using decay rate from large fallen coarse necromass. 
Edwards and Grubb (1977) found fallen dead wood mass of $10.9 \mathrm{Mg} / \mathrm{ha}$ in a rain forest in New Guinea. In a tropical forest in Australia, dead wood mass was 12 $\mathrm{Mg} / \mathrm{ha}$ (Grove 2001). In the Brazilian Amazon, measurements of fallen coarse necromass in undisturbed forests in terra firma include $48.0 \mathrm{Mg} \mathrm{C} / \mathrm{ha}$ (Rice et al. 2004) and $42.8 \mathrm{Mg} \mathrm{C} / \mathrm{ha}$ (Summers 1998) on the higher end, 27.6 Mg C/ha (Keller et al. 2004b), $15 \mathrm{Mg} \mathrm{C} / \mathrm{ha}$ (Brown et al. 1995), and 16.5 Mg C/ha (Gerwing 2002) for more central values, and $9.5 \mathrm{Mg} / \mathrm{ha}$ (Martius and Bandeira 1998) and $5.8 \mathrm{Mg} / \mathrm{ha}$ (Scott et al. 1992) on the lower end. In the floodplains of the Amazon, necromass was 1.8-5.7 Mg C/ha (Martius 1997). Other studies have examined coarse necromass in secondary forests and logged forests (Uhl et al. 1988, Gerwing 2002, Keller et al. 2004b, Palace et al. 2007).

The proportion of carbon in coarse necromass to total carbon in tropical forests has a wide range, $2 \%$ to $40 \%$ (Edwards and Grubb 1977, Brown 1997). The proportion of aboveground coarse necromass to aboveground biomass in tropical forests was measured at a range of tropical forest sites including 18\% (Keller et al. 2004b) to 33\% (Rice et al. 2004) at the Tapajos National Forest, $33 \%$ at the wet forest at La Selva in Costa Rica (Clark et al. 2002), and $2-18 \%$ for an altitudinal transect in Venezuela (Delaney et al. 1998). Standing dead stock was found to add an additional $11-30 \%$ to the total aboveground coarse necromass stock in central Amazonia (Klinge 1973, Higuchi and Biot 1995, Palace et al. 2007). Gerwing (2002) found standing dead to be $40 \%$ of the total coarse wood necromass stock in a disturbed forest that had been lightly logged and burned.

Measurements of standing dead stock often do not include stumps or trees $<1.3 \mathrm{~m}$ in height (Rice et al. 2004). We found that standing dead $<1.3 \mathrm{~m}$ in height accounted for $1.7-27.2 \%$ of the standing dead stock for our survey plots with an average of $4.9 \%$. This high proportion for standing dead stock to total coarse necromass suggests that necromass measurements in moist tropical forests should always include standing dead and preferably should also include stumps.

\section{Necromass sources}

Our examination of the proportions of fallen necromass source (trunk, branch, and unidentified) indicated that there is a significant difference between treatments within a production estimate or a pool estimate. We also found that the source proportions of fallen necromass were significantly different between production and pool estimates within treatments. RIL may have produced more material from trunks than UF because the RIL logging process includes vine cutting, which may strip out senescent branches prior to logging. Also, logging damages trees, which leads to subsequent mortality and greater whole tree death (Verissimo et al. 1992). Small and medium size class production proportionally had more branches in UF than RIL treatments. The small size class production source was made up of more trunks in RIL than UF. When we compare source proportions for production compared to pools, we do not find consistent proportions. UF treatments had more branch produced than in the pool, and RIL treatments had more trunks produced than in the pool. This could both show the influence of branch fall in an undisturbed forest and the influence of RIL methods of vine cutting and tree canopy loss due to tree felling.

We believe that branch fall from both live and standing dead trees is an important source of necromass production. Our field observations of standing dead necromass indicated that many trunks remain upright after limbs fall to the ground. Branches also fall from live trees. While we separated branches from trunks in our study, we did not directly measure branch fall because in the field it was frequently difficult to identify whether a branch had broken off from a tree before or after a whole tree fell. Ideally, measurements of coarse necromass source and pool would determine not just the source (trunk, unidentified, and branch), but also the mechanism that produced the coarse necromass (nonlethal disturbance or whole tree death).

\section{Simple model of production and decomposition}

The stock of necromass in a forest depends upon both the production and the decomposition of dead wood. The production of coarse necromass is an episodic event and decomposition of wood is a gradual process. We found it was easier to measure necromass production compared to decomposition so we modeled necromass with a simple first-order differential equation (Eq. 2) in order to estimate size-specific rates of decomposition. Stock estimates for necromass at the beginning and end of our study indicate only a small change in total necromass; therefore we believe that our steady-state assumption provides reasonable estimates, although the production data show some notable fluctuations, especially in 2004, as discussed previously.

For comparison with studies at other tropical forest sites, we focus on the necromass dynamics of undisturbed old-growth forests (UF). Our findings for the overall necromass pool decomposition constant $\left(0.15 \mathrm{yr}^{-1}\right)$, based on the steady state assumption, are similar to those found in Chambers et al. (2000, 2001b) and Rice et al. (2004), $0.13 \mathrm{yr}^{-1}$ and $0.12 \mathrm{yr}^{-1}$, respectively. Chambers et al. $(2000,2001 b)$ estimated a decomposition constant for material $>10 \mathrm{~cm}$ diameter, and Rice et al. (2004) based their estimates on work by Chambers et al. (2001b). A comparison of our results and those of Chambers et al. (2001b) suggests that coarse necromass $>10 \mathrm{~cm}$ diameter decomposes more rapidly in the forest studied at Manaus than at the Tapajos National Forest. This may be a result of the moister environment near Manaus or it could also be related to wood properties such as density. Given the much more rapid decomposition of necromass $<10 \mathrm{~cm}$ diameter, the apparent agreement between our study and these others is fortuitous. 


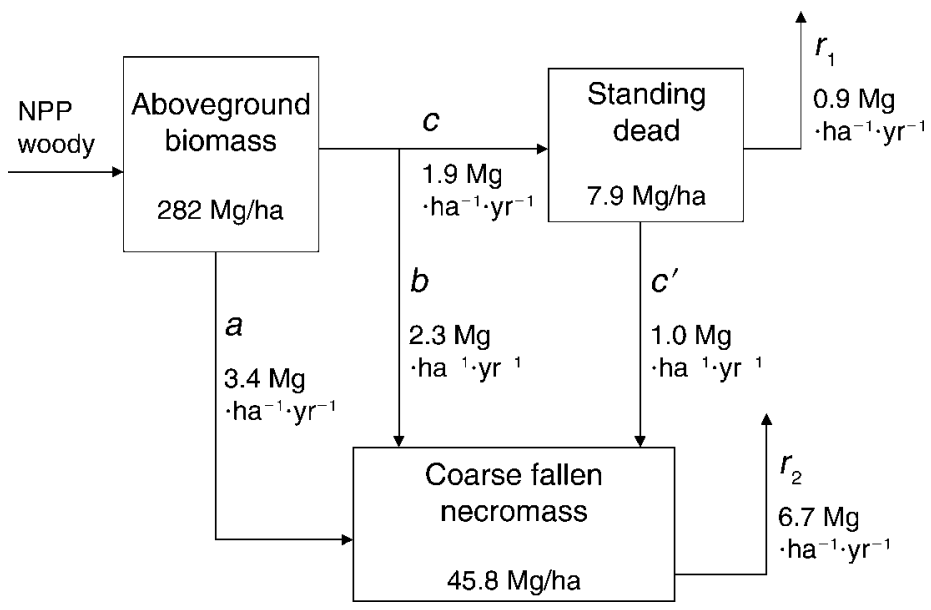

FIG. 2. A compartmental model of measured and estimated coarse necromass components where variables are defined as follows: $a$, nonlethal disturbance; $b$, fallen mortality that is not $a$ and $c ; c$, mortality that goes into the standing dead pool; $c^{\prime}$, standing dead that falls to forest floor (assumed steady state); $r_{1}$, decomposition from standing dead; and $r_{2}$, decomposition from fallen coarse necromass (assumed steady state). NPP stands for net primary productivity.
Decomposition constants varied from 0.03 to 0.52 $\mathrm{yr}^{-1}$ across six life zones in tropical forests in Venezuela (Delaney et al. 1998). In a dry tropical forest in Mexico, decomposition constants for coarse necromass varied from 0.008 to $0.615 \mathrm{yr}^{-1}$ (Harmon et al. 1995). Wilcke et al. (2005) estimated a decomposition constant of 0.09 $\mathrm{yr}^{-1}$ in a montane forest in Ecuador. A dry tropical forest study by Eaton and Lawrence (2006) yielded decomposition constants for large coarse necromass ranging from 0.134 to $0.643 \mathrm{yr}^{-1}$ and decomposition constants from 0.368 to $0.857 \mathrm{yr}^{-1}$ for small and medium necromass (with a minimum diameter of $1.8 \mathrm{~cm}$ ).

We summarize fluxes of coarse necromass in undisturbed forest in Fig. 2. There is a fundamental difference between our measured necromass production $\left(a+b+c^{\prime}\right.$ $\left.=6.7 \mathrm{Mg} \cdot \mathrm{ha}^{-1} \cdot \mathrm{yr}^{-1}\right)$ and the estimation of necromass production based on mortality rates $(b+c)$. Necromass production from nonlethal disturbance $(a)$ was found to be $3.4 \mathrm{Mg} \cdot \mathrm{ha}^{-1} \cdot \mathrm{yr}^{-1}$ using a combination of our measured production of standing dead $(c)$ and coarse necromass production from mortality rates $(b+c)$. When we compare the estimate of necromass production by a mortality estimate $\left(0.015 \mathrm{yr}^{-1}\right)$ multiplied by the aboveground biomass $(282 \mathrm{Mg} / \mathrm{ha})$, we find the resulting value $\left(4.2 \mathrm{Mg} \cdot \mathrm{ha}^{-1} \cdot \mathrm{yr}^{-1}\right)$ is only $55 \%$ of the sum of our measured annual fallen necromass production (6.7 $\left.\mathrm{Mg} \cdot \mathrm{ha}^{-1} \cdot \mathrm{yr}^{-1}\right)$ plus the decomposition of standing necromass $\left(0.9 \mathrm{Mg} \cdot \mathrm{ha}^{-1} \cdot \mathrm{yr}^{-1}\right)$.

Our measurement of coarse necromass production is close to the measurement of woody increment in living trees at Tapajos $\left(6.4 \mathrm{Mg} \cdot \mathrm{ha}^{-1} \cdot \mathrm{yr}^{-1}\right)$ found by Rice et al. (2004). The woody increment includes growth of branches and trunks based on allometric equations. Based on carbon balance from studies near Manaus, Brazil, Malhi et al. (2004) estimated that aboveground coarse wood production is $6.2 \mathrm{Mg} \cdot \mathrm{ha}^{-1} \cdot \mathrm{yr}^{-1}$.

Based on field measurements, the annual production of necromass pool was $8.5 \pm 1.3 \mathrm{Mg} \cdot \mathrm{ha}^{-1} \cdot \mathrm{yr}^{-1}$ in the RIL treatment and $6.7 \pm 0.8 \mathrm{Mg} \cdot \mathrm{ha}^{-1} \cdot \mathrm{yr}^{-1}$ in the undisturbed forest. Using the estimate from Chambers et al. (2001b) that $\sim 80 \%$ of necromass decomposition is lost to the atmosphere, we estimate carbon dioxide flux from fallen coarse necromass to be $3.4 \mathrm{Mg} \mathrm{C} \cdot \mathrm{ha}^{-1} \cdot \mathrm{yr}^{-1}$ for RIL sites and $2.7 \mathrm{Mg} \mathrm{C} \cdot \mathrm{ha}^{-1} \cdot \mathrm{yr}^{-1}$ for UF sites. Also we get an estimate of $20 \%$ or $1.7 \mathrm{Mg} \cdot \mathrm{ha}^{-1} \cdot \mathrm{yr}^{-1}$ for RIL sites and $1.3 \mathrm{Mg} \cdot \mathrm{ha}^{-1} \cdot \mathrm{yr}^{-1}$ for UF sites leached out of necromass or contributing to soil organic matter. When we add $0.45 \mathrm{Mg} \mathrm{C} \cdot \mathrm{ha}^{-1} \cdot \mathrm{yr}^{-1}$ for standing dead decomposition, total necromass carbon dioxide flux to the atmosphere is equivalent to $\sim 11-13 \%$ of the gross primary productivity based on a measurement of $30 \mathrm{Mg} \mathrm{C} \cdot \mathrm{ha}^{-1} \cdot \mathrm{yr}^{-1}$ by Miller et al. (2004) from the Tapajos National Forest. Coarse necromass production is $63 \%$ as large as the far more frequently measured fine litter production (6.0 Mg C $\cdot \mathrm{ha}^{-1} \cdot \mathrm{yr}^{-1}$ at Tapajos; Rice et al. [2004]).

\section{Conclusions}

RIL selective logging altered the stock of fallen necromass, but not the standing dead stock (Keller et al. 2004b, Palace et al. 2007). We found that RIL had $25 \%$ more coarse necromass production from the time we started measurement about one year following logging compared to undisturbed forest, although because of the limited power of our measurement design to detect rare tree falls for very large individuals, this difference was not statistically significant. In the undisturbed forest, necromass was equal to $14 \%$ of the total aboveground biomass and accounted for $\sim 13 \%$ of the total ecosystem respiration. Small diameter necromass $(2-5 \mathrm{~cm})$ and medium diameter $(5-10 \mathrm{~cm})$ necromass decomposed 4.2 and 3.0 times, respectively, more rapidly than large $(>10 \mathrm{~cm}$ diameter $)$ fallen necromass. The small and medium size classes accounted for $30 \%$ of the fallen necromass created, but only $14 \%$ of the total fallen coarse woody debris pools. Standing dead necromass accounts for up to $15 \%$ of the total necromass. Based on these findings, we encourage the inclusion of standing dead and fallen necromass $<10 \mathrm{~cm}$ diameter in future studies of coarse necromass in tropical forests.

We measured coarse necromass production to be 1.8 times greater than an estimate based on measured 
mortality rate and biomass stocks. Use of tree mortality alone to estimate coarse necromass production ignores branch fall, other crown damage, and other nonlethal disturbance processes and leads to a substantial (45\% in our case) underestimate of coarse necromass production. For carbon cycling studies, we have shown that direct measurement of the production of coarse necromass is more comprehensive than the more commonly used estimation of necromass production based on tree mortality rates alone.

\section{ACKNOWLEDGMENTS}

We thank Steve Frolking, John Aber, and George Hurtt for guidance and insightful comments on the paper. F. Ferreira Filho, Stephen Hagen, and Bobby Braswell assisted with field work. We also thank Bethany Reed, Lorena Brewster, and Raimundo Cosme de Oliveira, Jr., for their assistance with travel and logistics. The LBA Regional Office in Santarem provided logistical support. This study is a contribution to the Large Scale Biosphere Atmosphere Experiment in Amazonia led by Brazil's Ministry of Science and Technology. Support for this research was provided by the USDA Forest Service and the NASA Terrestrial Ecology Program (NCC5-225).

\section{Literature Cited}

Asner, G. P., E. N. Broadbent, P. J. C. Oliveira, D. E. Knapp, M. Keller, and J. N. Silva. 2006. Condition and fate of logged forests in the Brazilian Amazon. Proceedings of the National Academy of Sciences (USA) 103:12947-12950.

Asner, G. P., D. E. Knapp, E. N. Broadbent, P. J. C. Oliveira, M. Keller, and J. N. Silva. 2005. Selective logging in the Brazilian Amazon. Science 310:480-482.

Baker, T. R., et al. 2004. Variation in wood density determines spatial patterns in Amazonian forest biomass. Global Change Biology 10:545-562.

Brown, I. F., L. A. Martinelli, W. W. Thomas, M. Z. Moreira, C. A. C. Ferreira, and R. A. Victoria. 1995. Uncertainty in the biomass of Amazonian forests: an example from Rondonia, Brazil. Forest Ecology and Management 75: 175-189.

Brown, J. K. 1974. Handbook for inventorying downed woody material. GTR-INT-16. USDA Forest Service, Ogden, Utah, USA.

Brown, S. 1997. Estimating biomass and biomass change of tropical forests: a primer. United Nations Food and Agriculture Organization, Rome, Italy.

Chambers, J. Q., J. dos Santos, R. J. Ribeiro, and N. Higuchi. 2001a. Tree damage, allometric relationships, and aboveground net primary production in central Amazon forest. Forest Ecology and Management 152:73-84.

Chambers, J. Q., N. Higuchi, J. P. Schimel, L. V. Ferreira, and J. M. Melack. 2000. Decomposition and carbon cycling of dead trees in tropical forests of the central Amazon. Oecologia 122:380-388.

Chambers, J. Q., J. P. Schimel, and A. D. Nobre. $2001 b$. Respiration from coarse wood litter in central Amazon forests. Biogeochemistry 52:115-131.

Chambers, J. Q., E. S. Tribuzy, L. C. Toledo, B. F. Crispim, N. Higuchi, J. Dos Santos, A. C. Araújo, B. Kruijt, A. D. Nobre, and S. E. Trumbore. 2004. Tropical forest ecosystem respiration. Ecological Applications 14(Supplement):S72S88.

Chave, J., R. Condit, S. Lao, J. P. Caspersen, R. B. Foster, and S. P. Hubbell. 2003. Spatial and temporal variation of biomass in a tropical forest: results from a large census plot in Panama. Journal of Ecology 91:240-252.

Clark, D. A., S. Brown, D. W. Kicklighter, J. Q. Chambers, J. R. Thomlinson, and J. Nif. 2001a. Measuring net primary production in forests: concepts and field methods. Ecological Applications 11:356-370.

Clark, D. A., S. Brown, D. W. Kicklighter, J. Q. Chambers, J. R. Thomlinson, and J. Nif. 2001b. Net primary production in tropical forests: an evaluation and synthesis of existing field data. Ecological Applications 11:371-384.

Clark, D. B., D. A. Clark, S. Brown, S. F. Oberbauer, and E. Veldkamp. 2002. Stocks and flows of coarse woody debris across a tropical rain forest nutrient and topography gradient. Forest Ecology and Management 164:237-248.

Delaney, M., S. Brown, A. E. Lugo, A. Torres-Lezama, and N. B. Quintero. 1998. The quantity and turnover of dead wood in permanent forest plots is six life zones of Venezuela. Biotropica 30:2-11.

de Vries, P. G. 1986. Sampling theory for forest inventory. A teach-yourself course. Springer-Verlag, Berlin, Germany.

Eaton, J. M., and D. Lawrence. 2006. Woody debris stocks and fluxes during succession in a dry tropical forest. Forest Ecology and Management 232:46-55.

Edwards, P. J., and P. J. Grubb. 1977. Studies of mineral cycling in mountain rainforest in New Guinea, I. The distribution of organic matter in the vegetation and soil. Journal of Ecology 65:943-969.

Feldpausch, T. R., S. Jirka, C. A. M. Passos, F. Jasper, and S. J. Riha. 2005. When big trees fall: damage and carbon export by reduced impact logging in southern Amazonia. Forest Ecology and Management 219:199-215.

Gerwing, J. J. 2002. Degradation of forests through logging and fire in the eastern Brazilian Amazon. Forest Ecology and Management 157:131-141.

Grove, S. J. 2001. Extent and composition of dead wood in Australian lowland tropical rainforest with different management histories. Forest Ecology and Management 154:3553.

Harmon, M. E., et al. 1986. Ecology of coarse woody debris in temperate ecosystems. Advances in Ecological Research 15: 133-302.

Harmon, M. E., D. F. Whigham, J. Sexton, and I. Olmsted. 1995. Decomposition and mass of woody detritus in the dry tropical forests of the northeastern Yucatan peninsula, Mexico. Biotropica 27:305-316.

Higuchi, N., and Y. Biot. 1995. Convènio INPA/ODA: BIONTE. Biomassa florestal e nutrientes. Relatório semestral (Janeiro a junho 1995), volume 2. Unpublished report. Instituto Nacional de Pesquisas da Amazónia (INPA), Manaus, Brazil.

Kaarik, A. A. 1974. Decomposition of wood. Pages 129-174 in C. H. Dickinson and G. J. F. Pugh, editors. Biology of plant litter decomposition. Academic Press, New York, New York, USA.

Keller, M., et al. 2004a. Ecological research in the large scale biosphere atmosphere experiment in Amazônia (LBA): early results. Ecological Applications 14:s3-16.

Keller, M., M. Palace, G. P. Asner, R. Pereira, and J. N. M. Silva. 2004b. Coarse woody debris in undisturbed and logged forests in the eastern Brazilian Amazon. Global Change Biology 10:784-795.

Keller, M., M. Palace, and G. Hurtt. 2001. Biomass estimation in the Tapajos National Forest, Brazil: examination of sampling and allometric uncertainities. Forest Ecology and Management 154:371-382.

Kira, T. 1978. Community architecture and organic matter dynamics in tropical lowland rain forests of Southeast Asia with special reference to Pasoh Forest, West Malaysia. Pages 561-590 in P. B. Tomlinson and M. H. Zimmerman, editors. Tropical trees as living systems. Cambridge University Press, Cambridge, UK.

Klinge, H. 1973. Biomassa y materia orgánica del suelo in el ecosistema de la pluviselva centro-amazonica. Acta Cientifica Venezolana 24:174-181. 
Lang, G. E., and D. H. Knight. 1979. Decay rates for boles of tropical trees in Panama. Biotropica 11:316-317.

Malhi, Y., et al. 2004. The above-ground coarse woody productivity of 104 neotropical forest plots. Global Change Biology 10:563-591.

Martius, C. 1997. Decomposition of wood. Pages 267-276 in W. J. Junk, editor. The central Amazon floodplain. Ecology of a pulsing system. Ecological Studies 126. Springer, New York, New York, USA.

Martius, C., and A. G. Bandeira. 1998. Wood litter stocks in tropical moist forest in central Amazonia. Ecotropica 4:115118.

Miller, S. D., M. L. Goulden, M. C. Menton, H. R. da Rocha, H. C. de Freitas, A. M. Figuirea, and C. A. Dias de Sousa. 2004. Biometric and micrometeorological measurements of tropical carbon balance. Ecological Applications 14:s114126.

Nogueira, E. M., B. W. Nelson, and P. M. Fearnside. 2005. Wood density in dense forest in central Amazonia, Brazil. Forest Ecology and Management 208:261-286.

Odum, H. T. 1970. A tropical rain forest: a study of irradiation and ecology at El Verde, Puerto Rico. U.S. Atomic Energy Commission, National Technical Information Service, Springfield, Virginia, USA.

Ometto, J. P. H. B., A. D. Nobre, H. R. Rocha, P. Artaxo, and L. A. Martinelli. 2005. Amazonia and the modern carbon cycle: lessons learned. Oecologia 143:483-500.

Palace, M., M. Keller, G. P. Asner, J. N. M. Silva, and C. Passos. 2007. Necromass in undisturbed and logged forests in the Brazilian Amazon. Forest Ecology and Management 238: 309-318.

Pereira, R., J. C. Zweede, G. P. Asner, and M. M. Keller. 2002. Forest canopy damage and recovery in reduced impact and conventional logging in eastern Para, Brazil. Forest Ecology and Management 168:77-89.

Rice, A. H., E. H. Pyle, S. R. Saleska, L. Hutyra, P. B. Camargo, K. Portilho, D. F. Marques, M. Palace, M. Keller, and S. C. Wofsy. 2004. Carbon balance and vegetation dynamics in an old-growth Amazonian forest. Ecological Applications 14:s55-71.

Ringvall, A., and G. Stahl. 1999. Field aspects of line intersect sampling for assessing coarse woody debris. Forest Ecology and Management 119:163-170.

Roberts, D. A., M. Keller, and J. V. Soares. 2003. Studies of land-cover, land-use, and biophysical properties of vegetation in the Large Scale Biosphere Atmosphere experiment in Amazônia. Remote Sensing of Environment 87:377-388.
Saleska, S. R., et al. 2003. Carbon in Amazon forests: unexpected seasonal fluxes and disturbance-induced losses. Science 302:1554-1557.

Schulze, M., and J. Zweede. 2006. Canopy dynamics in unlogged and logged forest stands in the eastern Amazon. Forest Ecology and Management 236:56-64.

Scott, D. A., J. Proctor, and J. Thompson. 1992. Ecological studies on a lowland evergreen rain forest on Maracá Island, Roraima, Brazil. II. Litter and nutrient cycling. Journal of Ecology 80:705-717.

Silva, J. N. M., J. P. O. Carvalho, and J. C. A. de Lopes. 1995. Growth and yield of a tropical rainforest 13 years after logging. Forest Ecology and Management 71:267-274.

Silver, W. L., J. Neff, E. Veldkamp, M. Mcgroddy, M. Keller, and R. Cosme. 2000. The effects of soil texture on belowground carbon and nutrient storage in a lowland Amazonian forest ecosystem. Ecosystems 3:193-209.

Summers, P. M. 1998. Estoque, decomposição, e nutrientes da liteira grossa em floresta de terra-firme, na Amazônia Central. Ciencias de Florestas Tropicais. Instituto Nacional de Pesquisas da Amazônia, Manaus, Brasil.

Swaine, M. D., D. Lieberman, and F. E. Putz. 1987. The dynamics of tree populations in tropical forest: a review. Journal of Tropical Ecology 4:359-366.

Tanner, E. V. J. 1980. Studies on the biomass and productivity in a series of montane rain forests in Jamaica. Journal of Ecology 68:573-588.

Uhl, C., R. Buschbacher, and E. A. S. Serrão. 1988. Abandoned pastures in eastern Amazonia. Journal of Ecology 76:663681.

Veríssimo, A., P. Barreto, M. Mattos, R. Tarifa, and C. Uhl. 1992. Logging impacts and prospects for sustainable forest management in an old Amazonian frontier: the case of Paragominas. Forest Ecology and Management 55:169-199.

Vieira, S., P. Barbosa de Camargo, D. Selhorst, R. da Silva, L. Hutyra, J. Q. Chambers, I. F. Brown, N. Higuchi, J. dos Santos, S. C. Wofsy, S. E. Trumbore, and L. A. Martinelli. 2004. Forest structure and carbon dynamics in Amazonian tropical rain forests. Oecologia 140:468-479.

Wilcke, W., T. Hess, C. Bengel, J. Homeier, C. Valarezo, and W. Zech. 2005. Coarse woody debris in a montane forest in Ecuador: mass, $\mathrm{C}$ and nutrient stock, and turnover. Forest Ecology and Management 205:139-147.

Williamson, G. B., W. F. Laurance, A. A. Oliveira, P. Delamonica, C. Gascon, T. E. Lovejoy, and L. Pohl. 2000. Amazonian tree mortality during the 1997 El Nino drought. Conservation Biology 14:1538-1542. 